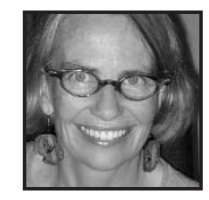

\title{
The Grief Beneath Your Mothertongue: Listening Through Poetic Inquiry
}

Sheila Stewart, Ontario Institute for Studies in Education, University of Toronto

\section{ABSTRACT}

This paper examines the process of writing a first poetry collection, A Hat to Stop a Train, as an example of poetic inquiry that has taught, and continues to teach about listening in and through language. It explores language as mothertongue, beginning with our relationships with our mothers and entwined with developing a poetic voice. Poetic inquiry brings insights into issues of silence and voice, loss and grief, for the author and her own writing, and also for the adult literacy learners she works with, whose circumstances and cultural and linguistic dislocations require careful listening.

My work is in loving the world. ${ }^{1}$

\author{
Mary Oliver, \\ from "The Messenger"
}

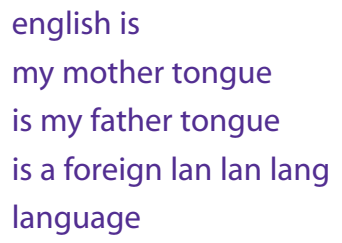




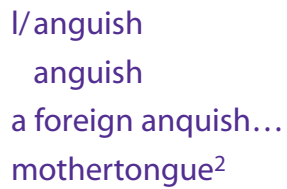

Marlene NourbeSe Philip, from "Discourse on the Logic of Language"

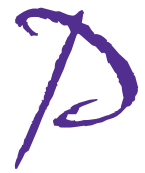

oems punctuate this paper. I attempt a dialogue between the poetry and prose. The poems can also be read in relation to each other as interior voices.

\section{In the beginning}

\section{word leapt from body}

and never returned. Body said, You're mine. Word said, I'm free. Page waited patiently knew word would want to lie down in time, would fall in love with crisp white sheets, with making a mark.

Edge along the page, and lie, still. ${ }^{3}$

A story has a beginning. A poem begins. We begin in the middle of things, our bodies holding our histories, our words struggling to know themselves.

A scholarly paper begins with an abstract, which summarizes and contextualizes the paper. Poems have different ways of beginning: they may leap in with both feet or slip in gently, knowing some things are best approached cautiously. Poems work with a sense of discovery and surprise, a showing, rather than a telling. They might hint, tease, captivate, shout; they rarely explain.

Here, I examine the process of writing my first poetry collection, $A$ Hat to Stop a Train, as an example of poetic inquiry that has taught, and continues to teach me about listening in and through language. Language is our mothertongue; our relationships with our mothers are our first alphabet. What can poetic inquiry teach me about my relationship with my mother, with language, and how can it inform my 
understanding of others' experiences of loss, their dislocations and grief? To speak, to write and to listen more deeply is to try to learn another language, the mothertongue beneath your mother tongue. Learning that mothertongue is closely tied to developing a voice that has both a tongue and a face. Through the use of poetic inquiry I am able to gain insights into issues of silence and voice, loss and grief, not only for myself and my own writing, but for those I work with, adult literacy learners whose circumstances and cultural and linguistic dislocations require my close listening.

\section{Poetic Inquiry}

Poetic inquiry is a fairly recent branch of arts-informed research, ${ }^{4}$ which has been developed in Canada by poet-academics Lorri Neilsen Glenn, Carl Leggo, Suzanne Thomas and others, working primarily in faculties of education. Poetry is an ancient art form, springing from oral language and song. Poems are already forms of inquiry; they don't need "poetic inquiry," but academia and sites of education need poetry. Academic inquiry needs the energy of the aesthetic and philosophical qualities of poetry. Lorri Neilsen Glenn speaks about lyric inquiry, a phrase she prefers to poetic inquiry. She says that lyric inquiry, "is informed by aesthetic and philosophical principles of writing; it is based on a conviction that using expressive and poetic functions of language creates the possibility of a resonant, ethical, and engaged relationship between the knower and the known."

Others have shaped our understandings of poetic inquiry, notably Monica Prendergast, Carl Leggo and Pauline Sameshima, as editors of and contributors to Poetic inquiry: Vibrant voices in the social sciences for an in-depth examination of poetic inquiry (2009). ${ }^{6}$ I gravitate towards poetic inquiry or lyric inquiry partly because of its newness in the academy, allowing space for me to do the poetic inquiry I need to do. I investigate the process of writing of $A$ Hat to Stop a Train as an example of poetic inquiry to learn more of what this poetic inquiry can teach me. In attempting to share the process of writing poetry about my mother, I re-enter that process, confronting my mother and myself anew, colliding with the complexities and conundrums of memory attempting to live in language. 


\section{Mothertongue Beneath Your Mother Tongue}

I use the word "mothertongue" partly out of homage to several important feminist poets, ${ }^{7}$ including Marlene NourbeSe Philip who uses "mothertongue" in its compound form. NourbeSe Philip's book She Tries Her Tongue, Her Silence Softly Breaks (1988) is written from the experience of a black Caribbean woman living in Toronto. Philip writes about colonialism, and the irony of the African Diaspora writing in English, the language of the colonizer. She says, "the excitement for me as a writer comes in the confrontation between the formal and the demotic within the text itself" (p. 18). Her work draws on the tension between these forms of language. She talks about how people of African descent "have been verbal or linguistic squatters, possessing adversely what is truly ours" (p. 21).

If the language is to continue to do what language must do; if it is to name and give voice to the i-mage and the experience behind the i-mage - the thing we conceive in our hearts - and so house the being, then the experience must be incorporated in the language and the language must begin to serve the re-creation of those i-mages." (p. 20)

NourbeSe Philip teaches me about the pain entwined in language for Canadian African Caribbean women. I return to her work hearing a complex meditation on grief, shame, and silence, which takes up the poet's task of re-creating the "image."

The word "mothertongue" burrows into the layers of our complex relationship with language, created through our cultural and social histories, begun with the relationship with a parent or parents, held in our bodies, and present in our voices. At the same time, the relational quality of language and learning as being between and among people is with us, even in its absence in settings where education is individual and competitive. Reading and writing poetry can take us back to the beginning of our relationship with language, the rhythm, the beat, the babble and bubble of learning language.

I explore the grief beneath my mothertongue out of a desire to embrace language and learning more fully. Through writing poetry that inquires in my mother's life and my relationship with her, I dwell with Irish idioms, the "craic" of my mother's generation, and stories about the Gaelic roots of some Northern Irish words amid a group of people many of whom see themselves as British. A Hat is part of the 
process of placing my story within individual and collective stories of grief, silence, and colonialism, as they relate to the complexities of language.

\section{Coming to Writing}

A Hat to Stop a Train is about my mother's childhood among her large family on a farm in Northern Ireland; her immigration to Canada with my father and my two older brothers; her work as a United Church minister's wife; and my relationship with her. There are many stories I could tell about the writing of my first book with certain key landmarks: my first writing course, Women's Writing Workshop, at George Brown College in 1991; my first poetry publication in Contemporary Verse 2 in 1992; performances done with the women in my first writing group; starting to see themes developing in my work; sending out my manuscript. But, the story I need to tell this time is about how my mother and my entwined stories relate to writing as a lifeline helping me uncover aspects of myself.

I went to that first writing class as a long-term journal keeper, nervous about writing pieces to share with others. I was expecting my first child. Those early writing years were connected with maternity leaves-putting the answering machine on when the baby slept, getting just enough time to start or revise a poem on a good day. Having grown up in small-town Ontario in a traditional Irish family, where my father's work was highly valued and my mother supported his work, I struggled to value my own words and find space and time for my writing. When I went to Sage Hill Writing Experience in Saskatchewan in 1997, a big part of the joy was ten days away from family and domestic responsibilities. Writing gave me some space and time away from family and work.

Meeting with my writing group supports my writing. My first writing group was a group of women prose writers and poets who originally met in the writing course at George Brown College. We met monthly in our homes. We read our work aloud. We learned how to listen to each other's work and give constructive feedback. We began to have our work published. I was writing poems about my mother while she was still alive.

My poetry is partly about the tenuousness of our connections with each other and with our selves. I write myself into existence in a certain sense, writing down what can so easily slip away, trying to craft something of daily experience, 
thoughts, and feelings. For me, writing is inquiry, craft, meditation, desire-the desire to fill, shape, know myself, and the desire to speak and be heard by another. I write alone, but I try to feel I write in the company of writing friends, colleagues, and loved ones, people who would like to listen.

Beneath the book's more obvious narrative themes is the theme of "voice." My voice has been bound up with my mother's. In A Hat my voice is entwined with the restraint of my Northern Irish background and childhood living in United Church manses in the small, southwestern Ontario communities of Stratford and Waterloo. The following poem from $A$ Hat speaks about the complexity of voice.

\section{What if a Voice}

What if a voice feels small, doesn't want to say, doesn't know how to sing, a voice in love with song but without a tune, a throat clogged up bad, words clunky and leaden, smell of untold stories, unformed words stuck mid-throat. No place to go.

What if a voice whines and attacks, picks and prods, can find no good, can't keep secrets, can't tell lies, can't hear herself.

What if a voice wants to hide in a child's choir gown, up in the balcony at the candle-light service, middle of the middle row so the words don't matter, mouthing Gloria in the dark, the tune her own.

What if the service is over but a voice won't come down, wants only the balcony and blown-out candles, hides under the pew 
singing to herself, sleeps on a choir gown pillow until light comes in through the stained glass, humming the hymns by heart.

II

What if a voice takes her own time, then startles with rush and flow.

What if a voice wants new snow, welcomes cool points on her tongue falling, long and lapping, fresh water in air, washing her face, single flakes and clusters rushing earthbound, thick along thin branches, cool song melting, claiming and changing the landscape.

I read this poem now a decade after writing it, dwelling in its current resonance as I wrestle to know what kind of academic voice I wish to have. Voice can feel small, want to hide, and turn on itself. In the second part of the poem,"voice takes her own time, then / startles with rush and flow." In a more embodied relationship, voice has a tongue and a face. She claims the landscape. Poetry builds on the physicality, cadences, directness, and sounds of spoken language. Poetry believes in the body as an instrument of knowing, its rhythmic awareness and sensations a gift.

In four years of undergraduate philosophy classes, I didn't speak. This was at the end of the 1970s/early 80 s and feminism had not reached humanities classes at Queen's University, Kingston, Ontario. In A Hat, I spoke to my mother, I spoke for her, I spoke with her, I spoke in her voice, I spoke as a child, and I spoke to the child I was. Though I didn't name them at the time, I was working to dislodge shame and silence, lodged in "a throat clogged / up bad." How do we lose and/or hide our voices? How can poetry and other forms of expressive writing help those of us who do? These large questions are beyond this paper; but an inquiry into writing is an in inquiry into self, culture, and the possibilities of language. I tried to be very good throughout 
school, good girl becoming good student. I blushed when called upon to speak, never feeling my speaking was adequate.

\section{I dreamed of being mute, dumb -}

not a sound out of me

In writing this article I let poetic fragments interrupt my prose. I could do this writing in a separate document, but I am trying to let this poetic voice take me further into my inquiry.

\section{Writing Mother, Writing Loss}

How do we write about such a complex subject as our mothers? My mother, Winifred Louise Ward, was born in 1919 in County Down, Northern Ireland and died in 1993 in Kingston, Ontario, Canada. Between the few facts of a life, lie story, memory, conjecture, interpretation. In "Signs of her"I sort her clothes after her death and wonder about "What I know and don't know about her." In "Two chairs" I am "trying to get closer to her." The first poem in the collection, "Ladybones," speaks of my longing for my mother, "Why do I want you, Skinamalink Malone, Skinny Bones. You the slim, delicate one." I, too, am a mother in this poem, "hip bones letting forth daughters." Another fact: when I was four years old, my mother underwent open-heart surgery with a fifty-fifty chance of living. She survived and lived another thirty years in delicate health. I don't write about the surgery directly in my poetry collection, but it is part of what fueled the book. After first meeting with the Wolsak and Wynn editors, amazed that they had read my manuscript, I wandered downtown Toronto and found myself having tea at Toronto General Hospital, the site of my mother's surgery.

In the middle

word wrestled with body. Body said, Word, you're a sham, a heady thing passed down from the fathers. You have forgotten your birth. Word was confused, wanting body's approval, a nod, a look, wordless

admiration. 
A Hat to Stop a Train is grief-work, a photograph of my mother as a young woman and her hatboxes on the cover. I speak to, with and for my mother, crafting this speaking over a decade as I was learning how to write poetry.

\section{in a seniors' home, an old man calls}

for his mother

Words comfort me. I attempt to create something from loss. When I started re-reading A Hat to write this article, it was as if my mother had died yesterday. I have read from the book in all kinds of venues to all kinds of audiences, but this was quiet reading to myself. On the one hand, I am happy that the book is still alive for me. On the other, I don't want to start missing my mother again. I don't want to dwell in thoughts of my mother. I don't want to think about her body. The book may have acted as a kind of container and I wanted the lid closed. Moving into my life as a writer attempting to use my mind and body as instruments of knowing, I am still learning to separate from my mother, attempting to leave behind her extreme politeness and restraint, and wifely ways of supporting others and diminishing herself.

A multitude of emotions lie within grief over the loss of a parent. It took time for anger to emerge, as it did in "Dress," written during my second time at Sage Hill Writing Experience in a Poetry Colloquium with Don MacKay in 1999.

\section{Dress}

You left me a thin flowered dress and a box of hankies. I can sit in your dress, sleeveless in the Canadian winter. Put it on and head to a strawberry social. Thank my lucky stars I'm in a pretty dress just my size. They can look and say, hey, she's been to a lady's dress shop in downtown Ontario.

I could sniff around the entrances of dress shops, or glide in the way you did. Never bat an eyelid at the prices. Pretend royalty.

Or I can sit in your dress and play with my box of hankies. A blue Birks' box about the size of a bread and butter plate. Take them out one by one, examine the embroidered garden scenes, the tatted edges, fold them up again, put them back. I could iron them all. Fold them in triangles. Sort them in piles. And crumple them. Use them as face cloths, dish cloths. Dirty them. 
Throw them out the windows of trains. Toss them like confetti from the top of the Royal York Hotel.

I'd still have the dress: I could hoist it up a flagpole. Hello, air. Let it grow grey, limp. Or yank it down. Pull out the threads one by one, bare the interfacing, rip out the zipper, knock its teeth crooked. Cut on the bias, it might rip real nice and smooth down the middle, or around the waist.

Rip it up, or cut it.You'd prefer I use pinking shears to cut zigzag edges in perfect circles, like the gingham ones that top jam jars at the Kitchener market.

Any scissors would do. Scraps of dress. Reds, greens, pinks. Purple poppies, variegated leaves, snips of stem.

A perfect plate for a tiny scone beaded with the red of strawberries.

I began to let anger emerge at my mother's high sense of decorum, and her version of being a woman. But, when I look at A Hat, I feel I am hiding behind my mother. The book is an early attempt to think and feel my way into understanding my relationship with my mother.

My mother left Ireland reluctantly with my father who wanted to immigrate to Canada. They crossed the Atlantic with two small sons. In the next poem, we hear something of my mother's loss, missing her six sisters and two brothers, who lived on nearby farms.

\section{Reading the Blues}

She called them Blues. Any

Blues? Thin blue

airmail letters from her sisters.

Any Blues? she'd call

to whoever brought in the mail. Sometimes

we'd pretend there were none, then draw them

from pockets or sleeves with

a flourish, or present them on a silver

tray - voila! - with a cup of tea and a digestive

biscuit. Any Blues? she'd call from her bed. 
What do we do with Blues?

Smell them, hold them tight,

read them slow, tuck them

under a pillow to re-read at night.

She wasn't a lady to cry

the blues. What didn't she say

to me, or herself? What can you tell

a mother anyway? Unwritten letters. Don't go

crying, she'd say.

What we tell

each other: a pale

picture, a slight blue.

How does a daughter bear witness to her mother's grief? How did the distance between my mother and her sisters affect my relationship with her? My writing contains a longing to connect and awareness of the partiality and flimsiness of words in our connections: "What we tell / each other: a pale / picture, a slight blue." Extraordinary grief lies in so-called "ordinary" losses, such as the death of a parent. Like so many emotions, grief can slip and slide into other emotions ${ }^{8}$ and pool in experiences which aren't even our own. For years I looked at my parents' photograph album of their early years in Ireland, an album which ends with pictures of my parents and brothers on the boat in which they emigrated from Ireland. Loss of homeland ripples through generations. In the case of my family, coming to Canada was chosen by my father. A job as a minister awaited my father and a manse awaited my mother and brothers. My parents didn't leave Ireland in the famine. They didn't pay a head tax or arrive in Canada as refugees or need to learn English on arrival. But their emigration marked my family, including myself born in Canada. I attempt to look up close at the grief within my relationship with my mother, her grief as she missed her family and homeland, her fragile health, my early care giving - grief an undercurrent in the language between us. I inquire into the nature of loss within a family, hoping the poem creates the space for the reader to do the same. Familial grief is set against the background of the sectarian violence of Northern Ireland and my mother's unpaid, rarely acknowledged work as a minister's wife. 


\section{In the middle}

page sent an invitation.

One of the poems "Not a body about" refers to a phrase my mother used when needing the zipper done up at the back of her dress. She said that her mother used to say, "not a body about to help me dress."I read the book now, looking for my body. I find my mother's.

In "She started to shed," I wrote "She started to shed / after her mother stopped breathing, after her mother's body, which she loved more than her own, was no longer in the world." What does it mean that I loved my mother's body more than my own? I use "I" here though the narrator and myself are not interchangeable. I am using first person as opposed to the academic tendency to talk about "the body."

In the manse we did not discuss our bodies. We read books, escaping family conflict and the disconnection among us. I learned to sit very still in church and daydream. I was the youngest daughter with two older brothers. In the manse, I learned to leave my body. I was worried about my mother's body. In a recent poem I write about the scar from my mother's surgery.

Learning the alphabet

I'd always known the letter $T$, the lines on my mother's chest, one across, another down between her breasts. A Roman cross. T for Turtle, Trunk, Time, Taste,

Trust. Never mentioned it, never touched it."No," she said, "I can't wear a neckline that low." My chest is uncut, skin intact. My children have all their limbs. The tiny suture on the last born is a faint thread.

"Inguinal hernia," they said."Better safe than sorry." The most recent: a squiggle above her eye, stitches from a slam against a window. We watch each other, my generation. What are the signs? Quiver

at the neck. A bit thinner. Talking, Truth, Touch. How do we keep each other alive? Look back at the seniors' home and my great-aunt is waving. She waits to hear if they'll operate. Her thin arms score the window. 
Our mothers' bodies are our first alphabets, usually our first connection to sustenance, intimate connection, and language. Poetry grows from the rhythm and rhyme of sound, which for most of us begins with our parents. Looking back at my book, I see how I was wrestling with a sense of my convergence with my mother.

\title{
It wasn't me
}

\begin{abstract}
who left
the Ballymena Manse, packed up my two small sons, arm in my husband's, stepped onto the boat. Landed in Montreal, took a train to Toronto, followed my sons from one car to the next, as they rubbed their good clothes along the floor. Not me arriving in Brechin, walking through the rooms of our new house, thank goodness the church ladies had made up the beds. Dinner at a parishioner's home and we watched to see how Canadians eat corn still on the cob. Not me
\end{abstract}

back at Carnlough, sitting mid a row of my friends, arms folded in our laps, husbands standing behind. There between Lily and Evelyn, ocean salt spraying our hair. That's not my first-born in the arms of his cousin. Not me with my mother. Here with an arm around each niece. Luminous at the Ordination Day of my husband-to-be. Not me picnicking at Curlingford Castle, in front of the Round Tower at Navan. Me sitting in the long grass with Josephine at Portstewart, eyes on the ocean. At Bradda Glen, in front of Balmoral Hotel, the Isle of Man, Ballyferris. I wasn't there. Sunday School picnic, my wide-brimmed hat, our big circle at Blackrock Beach.

In examining my mother's life, telling a version of her story, I use a refrain "not me" attempting to write myself out from behind my mother toward aspects of myself.

\section{In the midst}

$$
\text { of words, a body breathes, }
$$

says, I want a word to call my own.

Words aplenty: orbigularis oculi, nasalis,

levator labii superioris alaeque nasi, lips.

The Anatomy Colouring Book's 
muscles of facial expression.

Face moves

with

(out) a word.

\section{Loss and Listening}

Going through this process of writing poetry has opened me to learn more about the nature of literacy work. I worked for many years as an adult literacy practitioner at Parkdale Project Read, a Toronto community-based program, helping students tell and write their stories. The students had English as their first language, and were primarily born in the Caribbean or Canada. I was attracted to this work out of a desire to contribute to social justice, learn about poverty in Canada, and help people in an alternative education setting. As educators, how do we "read the blues" of our students? How do we hear their loss as different from, and in some ways similar to, our own? They may live far from family or have been without their support. Literacy students may have been labeled stupid, lazy, disabled, or "special" at home, school, and/or by other institutions and social relations. Students of colour experience racism and may have their language belittled as less than so-called "standard English." Our society fixates on so-called "normal,"9 marginalizing groups and individuals, seeing some people's minds in some bodies as less likely to learn. Who is listened to? Who is accustomed to being heard or not being heard? I am still examining the reasons I was drawn to listening to literacy students' stories. I want to understand more of how listening to self and other are entwined.

Growing up in the manse, I listened to my father's sermons on Sunday morning and often heard versions of them during the week. My father and older brothers discussed the sermon over Sunday lunch. My sense of injustice at who is listened to and who is valued has roots within my family story, as I observed whose backstage work supported whose voice.

One day I was awaiting a friend's poetry reading while writing a course paper on listening. I was struck with the sense of expectation I had before the reading, a kind of anticipatory preparing of my psyche. I settled in at the venue on arrival so that I would "receive" her reading. We often bring this kind of attention to art. We anticipate a poetry reading or a concert and we listen. We are open and hope to be surprised, startled, or moved. How differently we often listen to each other, at school, 
work and home, sometimes with weariness, imagining or unconsciously believing we know what the person will say before they speak. Our listening may be filtered through the narratives and stereotypes that crowd our heads.

Listening can be blocked by unexplored grief and shame sitting between students and teachers. A kind of space needs to be brought to listening, making it bearable and helpful. Writing poetry helps me create a kind of interior space which I want to filter into how I am in the world, including how I listen.

\section{In the middle}

a story builds, turns,

(an argument develops)

a body softens.

A body listens and some things in this world are hard to listen to.

Poetry and learning are both about making meaning and asking what it means to make meaning. Poetry can break away from narrative. It can subvert our story-making impulses. Certainly poetry and narrative are entwined, particularly in narrative poems and poetic stories. Another way to think of their domains is that poetry dwells in the moment and narrative over time. Narrative needs a beginning, middle, and an end, even if it questions these. Poetry is more irreverent with time, playing with it, less observant of it as a constraint. Poetry has a different relationship with narrative expectations and demands. It is akin to that part of our self which is below the worn-out stories we tell about ourselves, and which are told about us.

Listening can be heartbreaking, whether as a teacher listening to students and colleagues, or as a poet, listening to what is happening in the world. How do we respond to what we hear? What do we do with what we know?

\section{Listening Through Poetic Inquiry}

As an arts-informed researcher, I attempt to enliven inquiry through a process of dialogue between poetry and prose, a conversation between strains of 
thought and ways of expressing thought, complicating how we view content and form. I use poetic inquiry as a process of coming to know, a way of thinking-feeling, and being with my material, through a form of writing that creates space for a more embodied knowing. Poetry embraces partial knowing and imagistic knowing. Like a good open-ended question, it draws the reader/listener in, to create their own meaning by dwelling in complexity and often contradiction. It draws on aspects of the reader's conscious and unconscious thinking-feeling selves, and uses pleasure, play and humour as part of what makes engagement and learning possible. I read and write poetry because I feel accompanied by the paradoxical nature of poems. Poetry helps me say things I cannot say in other forms. I use poetry hoping it will reach a wider audience than more conventional academic writing. Poems punctuate this paper, helping to punctuate and possibly aerate thought.

\section{In the end}

no end for word, no end

of words, word games, word wonders, no need for word.

$$
\begin{array}{r}
\text { body needs care } \\
\text { like at the be } \\
\text { ginning }
\end{array}
$$

someone

to sit with

$$
\text { speak listen }
$$

wait for words

take up end

\section{less words}

To speak, to write and to listen more deeply is to try to learn another language, the mothertongue beneath your mother tongue. Poetry, like other art forms, creates space to work through aspects of self in relationship to others and the world, to find more satisfying ways of relating to language, and new forms of language. 


\section{Mothertongue}

needs

\section{attending}

let your spine relax

\section{from your tender}

arches

to the roof

of your mouth

NourbeSe Philip, and other poets writing from marginalized communities, point to the way language is implicated in the process of categorizing people. It can exclude, humiliate, and distance people. Language reflects and shapes what we know and what we think we can know. In attending to language, we notice our binary thinking, either/or, normal/abnormal, good/bad and so on. Poetry's facility with paradox, ambiguity, and uncertainty can be our teacher. I want to move beyond an outworn binary of poetic/academic language.

Poetry attempts to reckon with how the everyday world matters, the here and now. It helps us see afresh what is happening around us. Oliver's words inspire me:"My work is in loving the world."To edge toward knowing what "loving the world" might be for me, I examine the way I attempted to uncover more of the nature of the love between my mother and myself. $A$ Hat let me write toward my mother and eventually away from her, toward a clearer voice of my own. This poetic inquiry helped me begin to create more space for "loving the world." Poetry contains a freedom. It is less confined and prescribed than other forms of writing that are often hijacked by the need to tell official stories. As educators, the institutional writing we do, such as funding applications and activity reports, can cramp or confuse our thinking and practice. Poetry's irreverence and spacious listening helps us hold on to the way learning is life giving.

Poetry is a call and response. The poet and listener create the poem in the listening. Learning is like that too. We lean toward another, the learning alive between us. Sometimes we lean toward an aspect of self or the world and enter a dialogue. 
I end with a passage from Mary Oliver's poem, "The Messenger":

\section{Let me}

keep my mind on what matters,

which is my work,

which is mostly standing still and learning to be astonished. ${ }^{10}$

\section{Notes}

1. This phrase is from the poem "Messenger" in Thirst by Mary Oliver, 2006.

2. "Discourse on the Logic of Language" is from She Tries Her Tongue, Her Silence Softly Breaks by Marlene NourbeSe Philip, 1989. NourbeSe Philip examines how colonialism affects Black people, particularly Black women living in Canada, and the ways language, colonialism, and racism are entwined.

3. "In the beginning" first appears in Educational Insights, Volume 13, No. 3, 2009 as the first in a suite of poems entitled "How I want to keep saying it." This special issue on poetic inquiry is an excellent resource.

4. See Handbook of the Arts in Qualitative Research, J. Gary Knowles \& Ardra L. Cole (Eds.) and Creating Scholartistry: Imagining the Arts-informed Thesis or Dissertation, J. Gary Knowles, Sara Promislow, \& Ardra L. Cole (Eds.).

5. Neilsen Glenn, Lorri. (2008). "Lyric Inquiry." In Handbook of the Arts in Qualitative Research, J. Gary Knowles \& Ardra L. Cole (Eds.). (London: Sage Publications). p. 94.

6. See Lynn Butler-Kisber. (2010). "Poetic Inquiry." In Qualitative Inquiry: Thematic, Narrative and Arts-informed Perspectives. London: Sage; and Monica Prendergast, Carl Leggo and Pauline Sameshima (Eds.). (2009). "Poetic Inquiry" Educational Insights. Volume 13, No. 3 for an in-depth examination of poetic inquiry. 
7. Daphne Marlatt used the word "mothertongue" first in "with Mothertongue," in Room of One's Own, 8:4. (Jan. 1984, 53-56).

8. See Ahmed, Sara. (2004). The Cultural Politics of Emotion. New York: Routledge.

9. See Titchkosky, Tanya and Rod Michalko (Eds.). (2009). Rethinking normalcy: A disability studies reader. Toronto: Canadian Scholars' Press Inc. for a discussion of how disability studies helps us understand the problematic concept of "normal."

10. From the "Messenger" in Thirst by Mary Oliver, 2006.

\section{References}

Ahmed, S. (2004). The cultural politics of emotion. New York: Routledge.

Butler-Kisber, L. (2010). "Poetic inquiry." In Qualitative Inquiry: Thematic, Narrative and Arts-informed Perspectives. London: Sage.

Knowles, J.G., Promislow, S., \& Cole, A.L. (Eds.). (2008). Creating scholartistry: Imagining the arts-informed thesis or dissertation. Halifax, Nova Scotia: Backalong Books.

Knowles, J. G., \& Cole, A.L. (Eds.). (2008). Handbook of the arts in qualitative research: Perspectives, methodologies, examples, and issues. London: Sage Publications.

Marlatt, D. (1984). "with Mothertongue." In Room of One's Own, 8:4, 53-56.

Neilsen Glenn, L. (2008). "Lyric Inquiry." In Handbook of the Arts in Qualitative Research, J. G. Knowles \& A.L. Cole, (Eds.). London: Sage Publications, 93-102.
NourbeSe Philip, M. (1988). She tries her tongue, her silence softly breaks. Ragwood Press, Charlottetown.

Oliver, M. (2006). Thirst. Boston: Beacon Press.

Prendergast, M., Leggo, C., \& Sameshima, P. (Eds.). (2009). "Poetic Inquiry." Educational Insights. Volume 13, No. 3.

Prendergast, M., Leggo, C., \& Sameshima, P. (Eds.). (2009). Poetic inquiry: Vibrant voices in the social sciences. Rotterdam, The Netherlands: Sense Publishers.

Stewart, S. (2003). A hat to stop a train. Toronto: Wolsak and Wynn.

Stewart, S. (2009)."How I want to keep saying it." In M. Prendergast, C. Leggo, \& P. Sameshima (Eds.). (2009). "Poetic Inquiry." Educational Insights. Volume 13, No. 3.

Titchkosky, T., \& Michalko, R. (Eds.). (2009). Rethinking normalcy: A disability studies reader. Toronto: Canadian Scholars' Press Inc. 


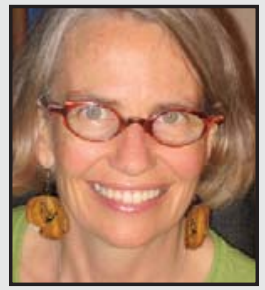

Sheila Stewart is an adult educator, poet and $\mathrm{PhD}$ student at the Ontario Institute for Studies in Education of the University of Toronto. Sheila has worked in adult literacy for many years. Sheila's poetry is widely published across Canada. Her collection A Hat to Stop a Train was published by Wolsak and Wynn in 2003. Sheila's thesis uses poetic inquiry to explore shame, grief, and silence as they relate to learning and language. Her literacy research includes work on the effect of violence on learning and the need for literacy practitioners to reflect on their identities.

\section{LINK TO:}

www.literaciesoise.ca/story.htm www.learningandviolence.net/movingresearch 